KAWISTARA

\title{
BIJAK MEMAKNAI PENYALINAN SEBAGAI WUJUD LAIN APRESIASI
}

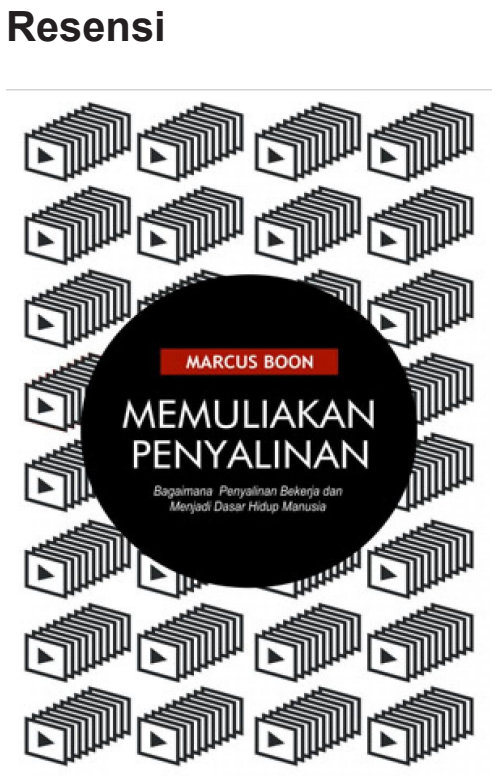

Judul Buku : Memuliakan Penyalinan

Penulis : Marcus Boon

Penerbit : Kunci Press

Halaman : 304 halaman

ISSBN : 978-602-19692-1-2

Resensi : Luthfy Avian Ananda

Dalam seluruh aspek kehidupan manusia, utamanya ketika kita memasuki lingkungan industri kreatif dan akademis, seakan diwajibkan untuk memberikan apresiasi terhadap karya orang lain. Apresiasi yang saya maksud ini bukan hanya sekadar dalam bentuk seseorang menyaksikan kemudian menikmati sebuah karya lalu memberikan penilaian positif.
Lebih dari itu, tunduk kepada hak cipta yang dimiliki oleh si empunya juga merupakan bentuk lain apresiasi terhadap sebuah mahakarya yang tak ternilai harganya.

Padahal jika kita telisik lebih dalam, sebenarnya meniru atau mengkopi juga termasuk dalam wujud lain apresiasi akan sebuah karya. Mengenai sebuah gaya berbusana misalnya, untuk saat ini banyak pemuda generasi milenial yang mengikuti cara berpakaian seorang Justin Bieber. Beruntungnya sang artis belum atau bahkan tidak akan pernah mendaftarkan sudut pandang fashionnya sebagai suatu hal yang eksklusif dan harus dilindungi oleh batasan hukum yang kaku bernama hak cipta. Karena jika sampai itu terjadi sudah barang tentu makna sebuah kata bernama "apresiasi" menjadi sangat terbatas. Hal ini sangat ironis, terkadang sudut pandang tertentu yang dipunyai oleh seorang tokoh, mampu menjadi trigger positif yang mempengaruhi kehidupan umat manusia, con- tohnya suday saya sebutkan di atas mengenai gaya berpakaian. Jika kehormatan berkedok hak cipta itu selalu diagung -agungkan, mungkin dunia saat ini akan terlihat sangat kuno.

Demikianlah garis besar dari pemikiran Marcus Boon yang kemudian dituangkan dalam sebuah buku berjudul in praise of copying (memuliakan penyalinan). Penulis yang juga merupakan seorang akademisi seakan mencoba untuk berpikir di luar kebiasaan manusia dalam memaknai kegiatan penyalinan yang akrab ditemukan dalam kehidupan sehari-hari. Bagi pembaca yang baru sepintas membaca judul ini saja, awalnya pasti akan berasumsi bahwa buku ini berisi mengenai larangan-larangan kaku yang melekat pada hak cipta karya seseorang. Apalagi jika sudah mengetahui kalau latar belakang sang penulis merupakan seorang akademisi, karena saya pun beranggapan demikian. Akan tetapi, setelah menyelami lebih dalam perihal isi di dalam buku ini, ter- 
nyata sangat jauh dari apa yang saya pikirkan di awal ketika akan membuka cover. Memang benar kata peribahasa, janganlah menilai sebuah buku hanya dari sampulnya saja, itu benar-benar berlaku untuk karya ini. Marcus Boon seakan berusaha meluruskan pandangan jika kegiatan menyalin, meniru, atau semacamnya itu tidak selamanya salah, namun juga tidak harus selalu dibenarkan. Semuanya perlu ditempatkan pada porsi yang tepat.

Ada bagian menarik ketika penulis berusaha memberikan konsep entertainment yang ditawarkan oleh Disney World sebagai sebuah contoh nyata penyalinan. Memang benar, di dalam wahana bermain tersebut pengunjung tidak hanya dihadapkan pada bentuk bangunan replika biasa, melainkan benar-benar mirip dengan aslinya. Mereka begitu detail membangun wahana permainan yang akan membuat pengunjung seperti berada di tempat yang sesungguhnya. Walaupun kenyataannya hanyalah sebuah replika, tetapi wujud kuil-kuil seperti yang dapat ditemukan di berbagai kota bersejarah penjuru dunia, orang mungkin akan merasa bahwa ia sedang mengelilingi dunia. Konsep wahana permainan fantasi semacam ini tentu tidak akan berhasil jika perancangnya tidak melakukan tiruan secara detail sama dengan bangunan aslinya. Seperti kata Marcus Boon, di Disney World kita semua akan sadar jika tindakan mengkopi itu adalah manusiawi. Menurut pandangan saya, dengan membaca buku ini berarti kita harus siap untuk sepakat menerima budaya penyalinan sebagai dasar hidup manusia. Tidak ada salahnya sedikit permisif dengan isu ini, karena kebiasaan mengkopi semacam ini merupakan sesuatu yang sudah merajalela.

Meskipun demikian, tetap terdapat hal-hal tertentu yang mengharuskan keberadaan hukum dan larangan-larangan lainnya mengatur tentang penyalinan. Misalnya dalam dunia akademis, untuk memenuhi syarat mendapatkan gelar akademik tertentu pastinya kita tidak akan bisa tanpa membuat sebuah karya ilmiah.
Sangat dilarang jika dilakukan dengan cara menyalin tulisan milik orang lain. Kalaupun terpaksa tetap harus dibutuhkan demi referensi, maka yang harus dilakukan adalah mencantumkan sumbernya. Etika akademik semacam ini tentu harus dihormati, di Indonesia sendiri sudah banyak contoh beberapa tokoh ternama yang gelar akademiknya terpaksa dicabut oleh institusi pendidikan lantaran terbukti melakukan plagiarism atas karya milik orang lain. Dengan membaca buku ini saya jadi berfikir bahwa di satu sisi budaya penyalinan berdampak baik sebagai pemicu perkembangan suatu budaya dan tradisi yang ada di seluruh dunia, seperti contoh yang sudah saya kemukakan di atas tentang fashion serta contoh lain dari sudut pandang Marcus Boon mengenai konsep penyalinan dalam wahana taman bermain di Disney world. Akan tetapi kebebasan penyalinan sangat berdampak buruk jika diterapkan dalam dunia akademis, pada akhirnya yang terjadi adalah terbatasnya konsep pemikiran antara satu manusia dengan yang lainnya.

Oleh sebab itu diperlukan adanya skripsi, tesis, maupun disertasi yang fresh dari berbagai kalangan akademisi agar sudut pandang manusia dalam memaknai suatu disiplin ilmu tertentu semakin berkembang. Batasan seperti ini masih dipegang teguh hingga sekarang, mungkin ini juga yang membuat banyak orang tidak benar-benar merasakan kebahagiaan sepenuhnya ketika melakukan penyalinan. Contohnya mahasiswa zaman sekarang, dengan kenyataan fasilitas digital dan internet yang semakin maju, mereka tentu sangat dimudahkan untuk menyelesaikan tugas dari dosen sekalipun itu berat. Terkadang ada yang mengambil jalan pintas untuk menelusuri jejak karya milik orang lain di mesin pencarian google demi sebuah nilai. Namun faktanya, selalu ada etika akademik yang menghantui sehingga membuat mereka tidak benar-benar bangga atas apa yang telah mereka lakukan. Perkembangan teknologi yang mengiringi kemajuan zaman membuat budaya salin- 
menyalin dalam aktifitas pembelajaran di universitas menjadi hal yang lazim ditemui Adanya hukum yang mengatur dan membatasi kegiatan pengkopian tersebut kemudian menjadikan setiap insan mahasiswa selalu hidup dalam perasaan bersalah. Sejujurnya, setelah membaca dengan seksama buku memuliakan penyalinan dari Marcus Boon ini, bukan hukumnya yang patut dipersalahkan, melainkan salah kaprahnya manusia dalam menempatkan kebiasaan penyalinan pada porsi yang tepat. Lalu bagaimana jika tidak pernah ada hukum maupun aturan baku lainnya yang mengatur ketentuan penyalinan, apakah umat manusia masih dihantui perasaan bersalah ketika melakukan tindakan ini. Jawabannya tentu iya, penjelasannya hakikat manusia merupakan makhluk yang memiliki kebiasaan buruk, ia tidak pernah puas meskipun sebuah karya yang dibuat sangat sempurna, apalagi jika itu terjadi atas hasil melanggar hak cipta milik orang lain. Bukan hukum yang akan menghukum mereka dengan perasaan bersalah, melainkan sisi batinnya yang menghakimi bahwa ia telah melakukan tindakan amoral berupa plagiarism.

Setidaknya saya juga pernah menemukan kejadian seperti ini dalam sebuah film berjudul the words yang diperankan oleh Bradley Cooper. Diceritakan dalam skenario tersebut, sang pemeran utama (Bradley Cooper) tidak sengaja menemukan sebuah naskah cerita kuno dari Perancis, ia sangat terhipnotis dengan tulisan tersebut lalu timbul keinginan untuk merasakan menulis semua kata-kata indah yang ada di dalamnya. Langkah itulah yang akhirnya mengantarkan dia menjadi penulis terkenal. Namun di kemudian hari ia secara tidak sengaja bertemu dengan penulis aslinya yang juga telah mengetahui bahwa karyanya telah dijiplak tanpa izin. Hingga sang penulis asli meninggal, sama sekali tidak pernah ada kompensasi yang diminta kepada Bradley Cooper. Namun sepanjang hidupnya pelaku plagiarism dalam film tersebut merasa terhukum dengan perasaan batinnya sendiri.
Sejauh itulah dampak dari budaya penyalinan yang sudah jamak terjadi dalam roda kehidupan manusia. Sekali lagi, baik atau buruknya akibat yang ditimbulkan, semua tergantung kita apakah dapat menyikapi hal itu secara tepat atau tidak. Belum tentu kebiasaan mengkopi sesuatu itu salah, namun tidak selamanya juga bisa dibenarkan. Akan menjadi kesalahan fatal apabila kita melakukannya dengan melanggar ranah pribadi milik orang lain seperti misalnya hak eksklusif yang timbul atas adanya hak cipta dalam sebuah karya. Keadaannya juga akan semakin parah jika kita sampai menodai etika akademik yang sangat dijaga kehormatannya dalam bidang pendidikan seperti yang sudah saya contohkan di atas. Buku memuliakan penyalinan dari Marcus Boon ini adalah tentang bagaimana manusia seharusnya menempatkan budaya penyalinan. Sebagai bentuk konsistensi pandangannya bahwa dalam suatu kondisi tertentu penyalinan itu diperbolehkan, Marcus Boon sendiri bahkan menerbitkan buku ini dengan lisensi creative commons sehingga orang dapat mengkopi dan membaginya dalam kondisi tertentu jika dibutuhkan dan menghasilkan manfaat yang baik bagi pembacanya.

Pola pikir out of the box dari penulis yang dituangkan melalui buku ini mengenai pandangannya tentang budaya penyalinan sangat menarik dijadikan referensi bagi kalangan mahasiswa, dosen, dan masyarakat umum. Kalangan akademisi penting untuk mempelajari buku ini secara mendalam agar di kemudian hari mereka tahu kapan waktu yang tepat untuk menentukan pilihan mengkopi atau tidak. Dengan demikian tidak akan ada lagi cerita akademisi yang hidup dalam keadaan bersalah karena kegagalannya dalam bersahabat dengan konflik batin akibat tindakan penyalinan. Bagi masyarakat pun demikian, pentingnya ialah agar publik tahu apresiasi bukan lagi terbatas dalam sekat menikmati dan memberikan pujian semata, tetapi keinginan untuk menyalin dan merasakan langsung kenikmatan membuat sebuah mahakarya juga merupakan salah satu bentuk apresiasi. Sama seperti yang diperan- 
kan oleh Bradley Cooper dalam film The Words. Mengutip kata-kata Gertrude Stein, "saya melihatnya dan saya mencintainya dan saya menuliskannya," kalimat ini mewakili perasaan beragam orang ketika berusaha mewujudkan apresiasi atas karya orang lain dengan cara mengkopinya. Tidak akan pernah ada yang membenarkan maupun menyalahkan penyalinan, buktinya Marcus Boon saja memperbolehkan pembacanya untuk bebas mengkopi buku ini.
Semua kembali kepada pilihan bijak kita untuk menentukan mau mengkopi atau tidak. Jika memang terpaksa harus menyalin karya orang lain, pastikan agar hal tersebut tidak digunakan untuk tindakan yang dapat merugikan si pembuatnya. Misalnya pemanfaatan penyalinan untuk kepentingan komersil, tentu akan sangat merugikan orang-orang hebat di balik terciptanya sebuah karya besar. 